\title{
A Bibliometric Analysis of Two Decades of Global Research on Organizational Ambidexterity using the Scopus Database
}

\author{
Asad Amjad, Khalil Md Nor
}

\begin{abstract}
Modern organizations face dynamism and due to which come across various performance challenges. Ambidexterity, which is the organizational balance among exploration and exploitation related activities, has gained significant attention in recent times on a global scale and is applicable in multiple domains. To advance the organizational ambidexterity understanding in an integrated and holistic manner, the current bibliometric analysis evaluates the globally published research conducted on organizational ambidexterity incorporating varied expressions. Using the Scopus database, the current research accumulated 282 journal articles from 1996 until 2018. The analysis of this research highlights, organizational ambidexterity research publications experienced a considerable upward momentum since year 2014 and onwards, with more than 40 papers per annum between 2015-2018. Top contributing institutions in organizational ambidexterity domain come from the United States, the United Kingdom, China, Spain, and Italy. Moreover, top-cited papers are from authors in the United States, the United Kingdom, and Netherlands. Most importantly, VOS viewer software is used to analyze co-authorship, author keyword co-occurrences, and network strength. The United States and the United Kingdom have the strongest link strength, followed by Canada, China, and South Korea, and Norway.
\end{abstract}

Keywords : Bibliometric analysis, Data mining, Network clustering, Organizational ambidexterity, Scopus database, VOS viewer.

\section{INTRODUCTION}

Globalization, technological advancements, information accessibility, and changing customer preferences exert pressures on businesses operating in both new and mature markets. Such pressures demand the development of new processes, products, services, knowledge, capabilities, and markets, known as exploration. Also, they demand the refinement and fine-tuning in the existing processes, products,

Revised Manuscript Received on March 16, 2020.

* Correspondence Author

Asad Amjad*, Azman Hashim International Business School / NUST Business School, Universiti Teknologi Malaysia (UTM) / National University of Sciences and Technology (NUST), Johor Bahru/Islamabad, Malaysia/Pakistan. Email: asad.aamjad@gmail.com

Khalil Md Nor, Azman Hashim International Business School, Universiti Teknologi Malaysia (UTM), Johor Bahru, Malaysia. Email: m-khalil@utm.my

(C) The Authors. Published by Blue Eyes Intelligence Engineering and Sciences Publication (BEIESP). This is an open access article under the CC BY-NC-ND license (http://creativecommons.org/licenses/by-nc-nd/4.0/) services, knowledge, capabilities, and markets regularly, known as exploitation. Exploration deals with the outside perspective, whereas, exploitation is associated with the inside perspective [1]. It becomes essential for organizations to keep pace with both the inside and outside perspective to be successful in the long-term. Focus on a single side, may result in a shortage on the other side, thereby resulting in an imbalance. The success of an organization lies in the balance among exploration and exploitation related activities for survival in the longer-run, as single-focused organizations may fall to the success or failure "traps" [2]. Ambidexterity, which is the organizational balance among exploration and exploitation related activities, has gained significant attention in recent times on a global scale and is applicable in multiple domains. Organizations, using ambidexterity may benefit and fulfil the performance requirements in dynamic and uncertain environments [3]. Empirical research supports ambidexterity to be beneficial for organizational performance, and an imbalance among the exploitation and exploration related activities reduces the possibility of organizational performance [4]. The current article is based on the bibliometric analysis of published organizational ambidexterity literature in Scopus journals from 1996 to 2018. Further details are discussed as follows.

\section{METHODS}

The methods employed in the current article are bibliometric analysis. The bibliometric analysis adopts data mining and quantitative methods to analyze and present the global research trends of a defined investigation area. The scope of the current article is to examine the organizational ambidexterity journal articles published in the Scopus database for more than two decades using bibliometrics. Scopus database serves as a data repository to mine for the relevant articles in the organizational ambidexterity domain. This paper examines the inherent trends and patterns deposited in these articles collectively.

\section{A. Search Strategy and Data Source}

Data is extracted using multiple keywords, mentioned below, in the Scopus search tool provided online. Based on the keywords, the Scopus database search is performed for an exact match with the title, abstract, or keywords of each of the documents stored in the Scopus database repository. Besides, data is limited to the published articles, in the English language.

Published By:

Blue Eyes Intelligence Engineering $\&$ Sciences Publication 


\section{A Bibliometric Analysis of Two Decades of Global Research on Organizational Ambidexterity using the Scopus Database}

This resulted in an output from the Scopus database, which is downloaded as a comma-separated value (CSV) excel file for later use with the VOS viewer software version 1.6.12 for analysis. The key terms searched for the current article are "organizational ambidexterity" or "ambidextrous organization" in the title, abstract and keywords. The data was mined using the following query on the Scopus database on September 30, 2019, using the advanced search feature: TITLE-ABS-KEY ( "organizational ambidexterity" OR "organisational ambidexterity" OR "ambidextrous organization" OR "ambidextrous organisation" ) AND DOCTYPE ( ar ) AND PUBYEAR < 2019 AND ( LIMIT-TO ( LANGUAGE , "English" ) ) The above query resulted in 282 Scopus journal articles. The output from the Scopus database is downloaded as a .csv excel file, which is provided to the VOS viewer software for the creation of textual and visual bibliometric maps and analysis. Data is cleansed using the 'Thesaurus' file, which is supplied to VOSviewer to label the textual co-occurrences during the map creation process. In this paper, the authors used 'Thesaurus' having labels to cleanse the data. E.g. 'firm performance' was labelled as 'organizational performance'. Appendix-A lists the complete set of labels used in the 'Thesaurus' for data cleansing for the bibliometric analysis presented in this paper.

\section{B. Bibliometric Maps}

Keywords, bibliographical, and citation information of 282 Scopus articles, stored in the excel file is provided into the VOS viewer software for data processing. The VOS viewer software produces the textual and visual bibliometric maps for further analysis and is an analysis tool, developed by Centre for Science and Technology Studies, Leiden University, Netherlands. VOS viewer visualizes and constructs the bibliometric linkages among pairs, such as institutions, countries, authors, publications. Such linkages are based on network strength, signifying the relationship strength among them. VOS viewer also allows bibliographic coupling, or co-authorship relations, citation, and co-citation analysis. Besides, VOS viewer allows text mining functionality which may be applied to create the visual co-occurrence networks of key terms derived through the literature.

\section{Co-author ship Analysis}

The co-authorship analysis accepts the country as the unit of analysis, to create a map. The researcher used a threshold value of 2 to both the minimum number of documents of a country and the minimum number of citations of a country to generate a map. Consequently, 37 of 44 countries associated with 160 authors, meet the threshold value for inclusion and are divided into 7 clusters having a unique color.

\section{Co-occurrence Analysis}

The co-occurrence analysis involves 747 keywords from 282 articles from 160 journals. Before keywords input to VOSviewer, the words and phrases with similar meaning are shortlisted and re-labelled using the VOSviewer thesaurus file. Appendix-A contains the list of identified words and phrases in Panel-A with the labels associated through review of Organizational Ambidexterity literature as listed in Panel-B. Besides, in VOSviewer, the threshold is set to three, resulting in 37 keywords to pass through among a total of 747. Next, we present the results, followed by the discussion.

\section{RESULTS AND DISCUSSION}

\section{A. Publication Growth, Output, and Research Interest}

A total of 282 articles in Scopus are published in more than two decades covering organizational ambidexterity up till end of year 2018. Fig. 1. Panel-A presents the trend of organizational ambidexterity (OA) papers yearly, where a rising trend, based upon three periods, is evident. The first era is less active with five or fewer articles yearly between 1996-2008. The second period has moderate activity and contributes 25 or fewer publications between 2009-2014. The third period, 2015-2018, offers nearly 50 articles annually. Panel-B of Fig. 1 presents the Scopus output and represents the literature coverage domain of organizational ambidexterity articles, and highlights organizational ambidexterity is a multi-disciplinary construct with (12\%) coverage other than business, management and accounting in disciplines like social sciences, engineering, psychology, computer science, economics and finance.

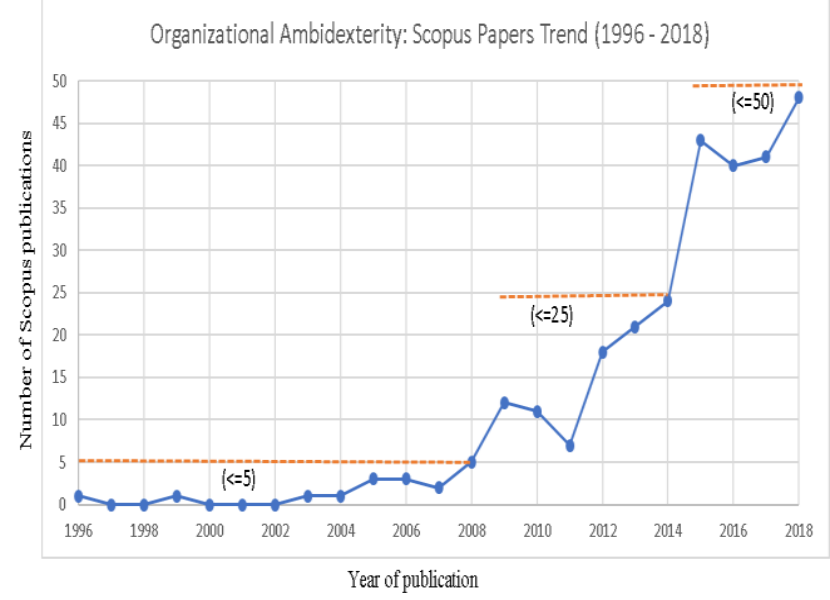

Fig. 1.Panel-A. Frequency of published OA Scopus articles

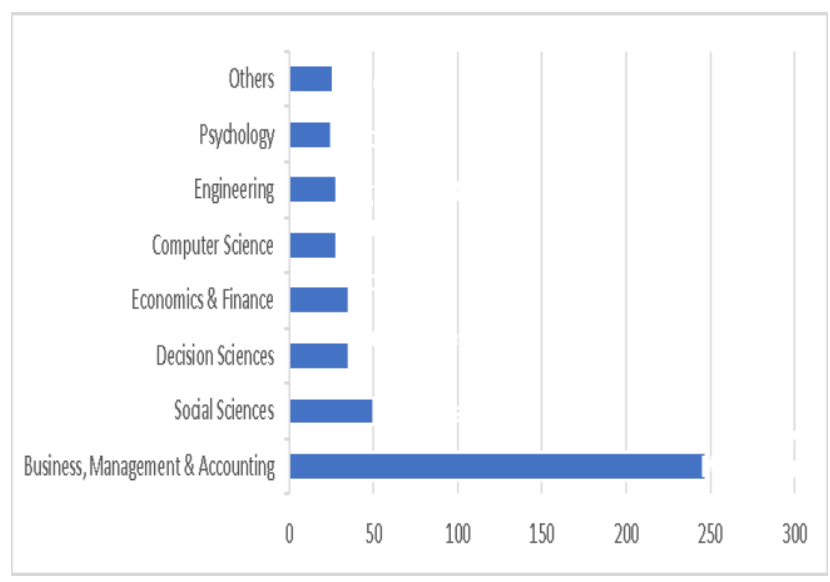

Fig.1. Panel-B. Domain of published OA Scopus articles

Published By:

Blue Eyes Intelligence Engineering \& Sciences Publication

(C) Copyright: All rights reserved. 


\section{B. Preferred Journals}

The top 10 journal list highlights the majority of the journals from varied publishers (Table-I).

The Organization Science, which contains the highest publications (11) covering (3.9\%) of the total publications, followed by Human Resource Management (8, 2.8\%), and Business Process Management Journal (7, 2.5\%). The most cited articles are published in Organization Science having 835 citations, followed by Academy of Management Perspectives (450 cites), and Journal of Management Studies (306 citations) respectively.

Based on the CiteScore (Cs) 2018, three journals including Journal of Management Studies, Academy of Management Perspectives, and Journal of Product Innovation Management have scores above five in the list. Besides, Journal of Management overall is at the top of the list having a CiteScore of 10.96. However, it contains three publications on organizational ambidexterity. For the clarity, CiteScore, and Impact Factor are the alternates used by Scopus and Web of Science respectively to highlight the impact of the journal.

Table- I: Top journals on OA with their top cited article.

\begin{tabular}{|c|c|c|c|c|}
\hline No & Journal (Publisher) & ${ }^{\mathrm{a}} \mathbf{T p},(\%)$ & $\begin{array}{l}{ }^{\mathrm{a}} \mathrm{Tc},( \\
{ }^{\mathrm{a}} \mathrm{Cs} \\
\text { 2018) }\end{array}$ & $\begin{array}{l}\text { Most cited } \\
\text { article, } \\
\text { Times } \\
\text { cited }\end{array}$ \\
\hline 1 & $\begin{array}{ll}\begin{array}{l}\text { Organization } \\
\text { (Informs) }\end{array} & \text { Science } \\
\end{array}$ & $\begin{array}{l}11 \\
(3.9 \%)\end{array}$, & $\begin{array}{l}3041 \\
(4.76)\end{array}$ & {$[5], 835$} \\
\hline 2 & $\begin{array}{lc}\text { Human } & \text { Resource } \\
\text { Management (Wiley) }\end{array}$ & $\begin{array}{l}8, \\
(2.8 \%)\end{array}$ & $\begin{array}{l}184, \\
(4.28)\end{array}$ & {$[6], 45$} \\
\hline 3 & $\begin{array}{ll}\begin{array}{l}\text { Business } \\
\text { Management } \\
\text { (Emerald) }\end{array} & \begin{array}{l}\text { Process } \\
\text { Journal }\end{array} \\
\end{array}$ & $\begin{array}{l}7 \\
(2.5 \%)\end{array}$ & $\begin{array}{l}25 \\
(2.98)\end{array}$ & [7], 10 \\
\hline 4 & $\begin{array}{l}\text { Journal Of Management } \\
\text { Studies } \\
\text { (Wiley-Blackwell) }\end{array}$ & $\begin{array}{l}7 \\
(2.5 \%)\end{array}$ & $\begin{array}{l}1119 \\
(5.99)\end{array}$ & [8], 306 \\
\hline 5 & $\begin{array}{l}\text { Journal Of } \begin{array}{r}\text { Product } \\
\text { Innovation Management } \\
\text { (Wiley) }\end{array} \\
\end{array}$ & $\begin{array}{l}7 \\
(2.5 \%)\end{array}$ & $\begin{array}{l}187, \\
(5.43)\end{array}$ & [9], 56 \\
\hline 6 & $\begin{array}{l}\text { Technological } \\
\text { Forecasting And Social } \\
\text { Change (Science Direct) }\end{array}$ & $\begin{array}{l}7 \\
(2.5 \%)\end{array}$ & $\begin{array}{l}122 \\
(4.32)\end{array}$ & [10], 52 \\
\hline 7 & $\begin{array}{lr}\text { International } & \text { Journal Of } \\
\text { Human } & \text { Resource } \\
\text { Management } & \text { (Taylor \& } \\
\text { Francis) } & \\
\end{array}$ & $\begin{array}{l}6 \\
(2.1 \%)\end{array}$ & $\begin{array}{l}74 \\
(2.71)\end{array}$ & [11], 24 \\
\hline 8 & $\begin{array}{ll}\begin{array}{l}\text { Management } \\
\text { (Emerald) }\end{array} & \text { Decision } \\
\end{array}$ & $\begin{array}{l}6 \\
(2.1 \%)\end{array}$ & $\begin{array}{l}121, \\
(2.74)\end{array}$ & [12], 78 \\
\hline 9 & $\begin{array}{l}\text { Academy Of } \\
\text { Management } \\
\begin{array}{l}\text { Perspectives (Academy } \\
\text { of Management) }\end{array} \\
\end{array}$ & $\begin{array}{l}4, \\
(1.4 \%)\end{array}$ & $\begin{array}{l}856 \\
(5.92)\end{array}$ & [3], 450 \\
\hline 10 & $\begin{array}{l}\text { Long Range Planning } \\
\text { (Science Direct) }\end{array}$ & $\begin{array}{l}4 \\
(1.4 \%)\end{array}$ & $\begin{array}{l}180 \\
(4.42)\end{array}$ & [13], 112 \\
\hline
\end{tabular}

${ }^{\text {a. }}$ Tp:total publications; Tc:total citations; Cs: cite score.

A comprehensive list of journals for organizational ambidexterity articles is compiled and available in Appendix-B.

\section{Prominent Institutions, Countries, and Worldwide Collaborations}

Based on Fig.2, the United States, the United Kingdom, and China are the top three countries in organizational ambidexterity research followed by European countries including Spain, Italy, France, Germany, Sweden,
Netherlands along with Australia and Taiwan respectively.

Interestingly, in the single country publications, Taiwan (83.3\%), Sweden (71.4\%), Spain (69.6\%), and China (62.1\%) produces most of their research indigenously and involve less (between $16.7 \%$ to $37.9 \%$ ) in global collaborative organizational ambidexterity publications.

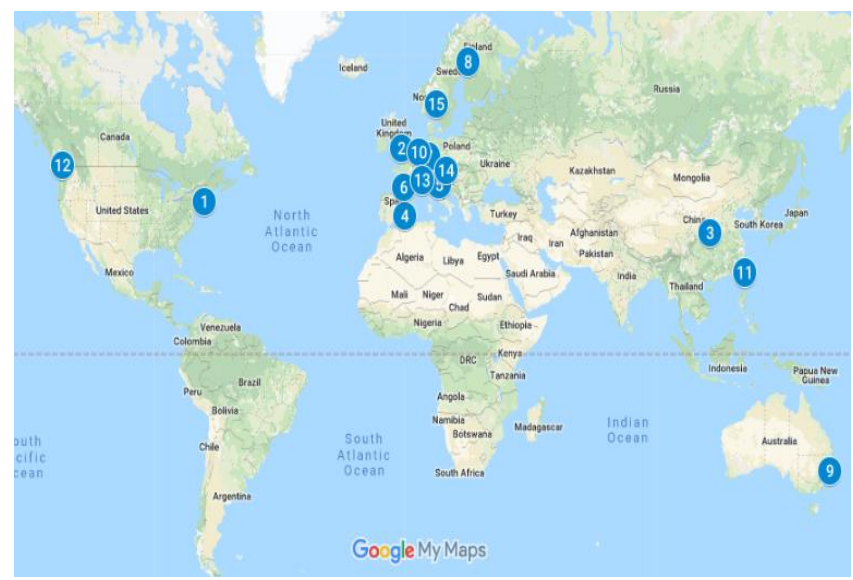

Fig. 2. Most productive countries and academic institutions in $\mathrm{OA}$ publication.

Importantly, the United States and the United Kingdom are leading the number of organizational ambidexterity publications and contribute $50 \%$ of their research from within the country, and the rest $50 \%$ with global collaborations. Canada (90\%) and Norway

Table- II: Top countries and institutes in OA publication.

\begin{tabular}{|c|c|c|c|c|c|}
\hline Rank & Country & ${ }^{{ }^{\mathrm{a}} \mathbf{T P c}}$ & ${ }^{\mathrm{a} S C P}$ & $\begin{array}{c}\text { Most productive } \\
\text { institution }\end{array}$ & ${ }^{\mathrm{a}} \mathbf{T P i}$ \\
\hline 1 & $\begin{array}{l}\text { United } \\
\text { States }\end{array}$ & 72 & 50.0 & $\begin{array}{ll}\text { University } & \text { of } \\
\text { Connecticut } & \end{array}$ & 6 \\
\hline 2 & $\begin{array}{l}\text { United } \\
\text { Kingdom }\end{array}$ & 46 & 50.0 & $\begin{array}{l}\text { Warwick Business } \\
\text { School }\end{array}$ & 6 \\
\hline 3 & China & 29 & 62.1 & $\begin{array}{l}\text { Xi'an Jiaotong } \\
\text { University }\end{array}$ & 4 \\
\hline 4 & Spain & 23 & 69.6 & $\begin{array}{l}\text { University of } \\
\text { Alicante }\end{array}$ & 6 \\
\hline 5 & Italy & 18 & 50.0 & $\begin{array}{l}\text { University } \quad \text { Of } \\
\text { Padova }\end{array}$ & 4 \\
\hline 6 & France & 15 & 26.7 & $\begin{array}{l}\text { KEDGE Business } \\
\text { School }\end{array}$ & 2 \\
\hline 7 & Germany & 14 & 42.9 & $\begin{array}{l}\text { University of } \\
\text { Siegen }\end{array}$ & 2 \\
\hline 8 & Sweden & 14 & 71.4 & $\begin{array}{l}\text { LuleåTekniska } \\
\text { Universitet }\end{array}$ & 3 \\
\hline 9 & Australia & 13 & 46.2 & $\begin{array}{l}\text { University of } \\
\text { Newcastle, } \\
\text { Australia }\end{array}$ & 2 \\
\hline 10 & Netherlands & 12 & 58.3 & $\begin{array}{l}\text { Rotterdam School } \\
\text { of Management }\end{array}$ & 7 \\
\hline 11 & Taiwan & 12 & 83.3 & $\begin{array}{l}\text { National Dong } \\
\text { Hwa University }\end{array}$ & 4 \\
\hline 12 & Canada & 10 & 10.0 & $\begin{array}{ll}\text { Simon } & \text { Fraser } \\
\text { University } & \\
\end{array}$ & 3 \\
\hline 13 & Switzerland & 9 & 44.4 & $\begin{array}{l}\text { Université } \\
\text { Genève }\end{array}$ & 3 \\
\hline 14 & Austria & 8 & 37.5 & $\begin{array}{l}\text { Johannes Kepler } \\
\text { Universitat Linz }\end{array}$ & 5 \\
\hline 15 & Norway & 8 & 0.0 & $\begin{array}{l}\text { Handelshøyskolen } \\
\text { BI }\end{array}$ & 4 \\
\hline
\end{tabular}

TP: Total publications (c: country-wise; i: institution-wise); SCP: Single country publication.

Published By:

Blue Eyes Intelligence Engineering \& Sciences Publication 


\section{A Bibliometric Analysis of Two Decades of Global Research on Organizational Ambidexterity using the Scopus Database}

(100\%) on the other hand, are among the highest in global collaborative publications rather focusing indigenously in such research.

On the basis on Table-II, the most prolific institutions in terms of total number of articles on organizational ambidexterity is the Rotterdam School of Management, Netherlands (7), followed by University of Alicante (Spain), University of Connecticut (United States) and Warwick Business School (United Kingdom) producing six publications by each institution.

The co-author analysis (Fig.3) presents that the United States is leading in global co-authorship with highest 18 links among 3 clusters with a total link strength of 52 .

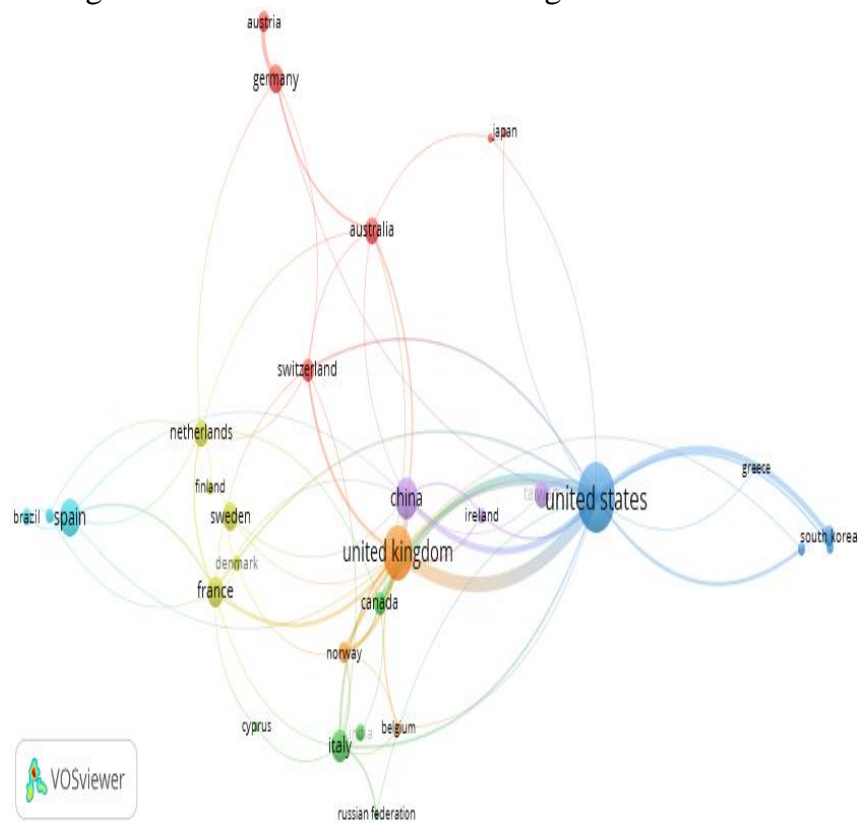

Fig. 3. A bibliometric network of co-authorship in VOSviewer

Moreover, the United Kingdom follows with 13 links in 7 clusters, with a total link strength of 35 . Besides, France, on the third, has a total of 10 links in 4 clusters, having a link strength of 15. It is to mention, that the thicker lines in Fig.3 by VOSviewer, represent higher link strength and collaboration among the two countries.

\section{Prominent Authors}

The top fifteen prominent authors in organizational ambidexterity belong to six countries, as listed in Table-III, with Netherlands having three authors, the United States (2 authors), Spain (3 authors), the United Kingdom (3 authors), Italy (1 authors), and China with (1 author).

Table- III: Prominent authors in OA publication.

\begin{tabular}{|l|l|l|l|l|l|}
\hline No & $\begin{array}{l}\text { Author, } \\
\text { (Scopus ID) }\end{array}$ & $\begin{array}{l}\text { Docs, } \\
\text { ( H } \\
\text { index) }\end{array}$ & $\begin{array}{l}\text { Publish } \\
\text { Year, } \\
\text { (Cites) }\end{array}$ & $\begin{array}{l}\text { Current } \\
\text { affiliation }\end{array}$ & Country \\
\hline 1 & $\begin{array}{l}\text { Volberda, H.W., } \\
\text { (6701307964) }\end{array}$ & $6,(43)$ & $\begin{array}{l}2006 c, \\
(1958)\end{array}$ & $\begin{array}{l}\text { Erasmus } \\
\text { University } \\
\text { Rotterdam }\end{array}$ & $\begin{array}{l}\text { Nether- } \\
\text { lands }\end{array}$ \\
\hline 2 & $\begin{array}{l}\text { Tushman, M.L., } \\
(6602681606)\end{array}$ & $6,(40)$ & $\begin{array}{l}1996 a, \\
(3383)\end{array}$ & $\begin{array}{l}\text { Harvard } \\
\text { Business } \\
\text { School }\end{array}$ & $\begin{array}{l}\text { United } \\
\text { States }\end{array}$ \\
\hline 3 & $\begin{array}{l}\text { Jansen, J.J.P., } \\
(12244592100)\end{array}$ & $5,(17)$ & $\begin{array}{l}\text { 2006a, } \\
(1912)\end{array}$ & $\begin{array}{l}\text { Erasmus } \\
\text { University }\end{array}$ & $\begin{array}{l}\text { Nether- } \\
\text { lands }\end{array}$ \\
\hline 4 & $\begin{array}{l}\text { Marco-Lajara, } \\
\text { B(55496694500) }\end{array}$ & $5,(10)$ & $2016 c,(27)$ & $\begin{array}{l}\text { Universitat } \\
\text { d'Alacant, }\end{array}$ & Spain \\
\hline
\end{tabular}

\begin{tabular}{|c|c|c|c|c|c|}
\hline 5 & $\begin{array}{l}\text { Úbeda-García, M., } \\
\text { (55578413500) }\end{array}$ & $5,(10)$ & $\begin{array}{l}\text { 2016b, } \\
(27)\end{array}$ & $\begin{array}{l}\text { Faculty of } \\
\text { Science, } \\
\text { Alicante }\end{array}$ & Spain \\
\hline 6 & $\begin{array}{l}\text { Birkinshaw, J., } \\
\text { (7003272873) }\end{array}$ & $4,(47)$ & $\begin{array}{l}\text { 2004b, } \\
(2752)\end{array}$ & $\begin{array}{l}\text { London } \\
\text { Business } \\
\text { School } \\
\end{array}$ & $\begin{array}{l}\text { United } \\
\text { Kingdo } \\
\mathrm{m}\end{array}$ \\
\hline 7 & $\begin{array}{l}\text { Claver-Cortés, E., } \\
(14048052100)\end{array}$ & $4,(25)$ & $\begin{array}{l}\text { 2016b, } \\
(17)\end{array}$ & $\begin{array}{l}\text { Faculty of } \\
\text { Science, } \\
\text { Alicante }\end{array}$ & Spain \\
\hline 8 & $\begin{array}{l}\text { Simsek, Z., } \\
\text { (6603090088) }\end{array}$ & $4,(24)$ & $\begin{array}{l}\text { 2009a, } \\
(672)\end{array}$ & $\begin{array}{l}\text { Clemson } \\
\text { University }\end{array}$ & $\begin{array}{l}\text { United } \\
\text { States }\end{array}$ \\
\hline 9 & $\begin{array}{l}\text { Nosella, A., } \\
\text { (8296511700) }\end{array}$ & $4,(13)$ & $\begin{array}{l}\text { 2012c, } \\
(112)\end{array}$ & $\begin{array}{l}\text { Università } \\
\text { degli Studi di } \\
\text { Padova, Padua }\end{array}$ & Italy \\
\hline 10 & $\begin{array}{l}\text { Li, C.R., } \\
\text { (24503574100) }\end{array}$ & $4,(11)$ & $\begin{array}{l}\text { 2008a, } \\
(116)\end{array}$ & $\begin{array}{l}\text { Jilin } \\
\text { University, } \\
\text { Changchun } \\
\end{array}$ & China \\
\hline 11 & $\begin{array}{l}\text { Fu, N., } \\
\text { (55248932300) }\end{array}$ & $4,(7)$ & 2015a, (34) & $\begin{array}{l}\text { Trinity } \\
\text { Business } \\
\text { School } \\
\end{array}$ & $\begin{array}{l}\text { United } \\
\text { Kingdo } \\
\mathrm{m}\end{array}$ \\
\hline 12 & $\begin{array}{l}\text { Smith, S.M., } \\
\text { (56069453200) }\end{array}$ & 4, (4) & 2015c, (32) & $\begin{array}{l}\text { University of } \\
\text { Winchester }\end{array}$ & $\begin{array}{l}\text { United } \\
\text { Kingdo } \\
\mathrm{m}\end{array}$ \\
\hline 13 & $\begin{array}{l}\text { O'Reilly, C.A., } \\
\text { (7005911757) }\end{array}$ & $3,(40)$ & $\begin{array}{l}\text { 1996b, } \\
(2336)\end{array}$ & $\begin{array}{l}\text { Stanford } \\
\text { University }\end{array}$ & $\begin{array}{l}\text { United } \\
\text { States }\end{array}$ \\
\hline 14 & $\begin{array}{l}\text { Van Den Bosch, } \\
\text { F.A.J., } \\
\text { (7006104929) }\end{array}$ & 3, (34) & $\begin{array}{l}\text { 2006b, } \\
(1473)\end{array}$ & $\begin{array}{l}\text { Erasmus } \\
\text { University } \\
\text { Rotterdam } \\
\end{array}$ & $\begin{array}{l}\text { Nether- } \\
\text { lands }\end{array}$ \\
\hline 15 & $\begin{array}{l}\text { Andriopoulos, C., } \\
\text { (10642423900) }\end{array}$ & $3,(15)$ & $\begin{array}{l}\text { 2009a, } \\
\text { (789) }\end{array}$ & $\begin{array}{l}\text { City } \\
\text { University of } \\
\text { London } \\
\end{array}$ & $\begin{array}{l}\text { United } \\
\text { Kingdo } \\
\mathrm{m}\end{array}$ \\
\hline
\end{tabular}

$\mathrm{a}=$ First author, $\mathrm{b}=$ Co-author, $\mathrm{c}=$ Last author

H.W. Vorberda along with M.L.Tushman are among the most prolific authors having six articles each, followed by J.J.P. Jansen, B. Marco-Lajara, and M. Ubeda-Garcia having five publications each. M.L.Tushman, J. Birkinshaw, and C.A. O'Reilly are the top cited authors in organizational ambidexterity with 3383, 2752, and 2336 citations respectively as listed in Table-III.

\section{E. Authors Keywords}

This paper recorded a total of 1265 keywords by the authors, out of which 743 (58.7\%) occurred a single time, 100 keywords (7.9\%) transpired for two times, 33 keywords (2.6\%) happened for three times. After the treatment of re-labelling similar phrases and synonyms, 19 keywords adhered the boundary of atleast five occurrences for mapping in the VOSviewer as listed in Fig.4.

humancapital

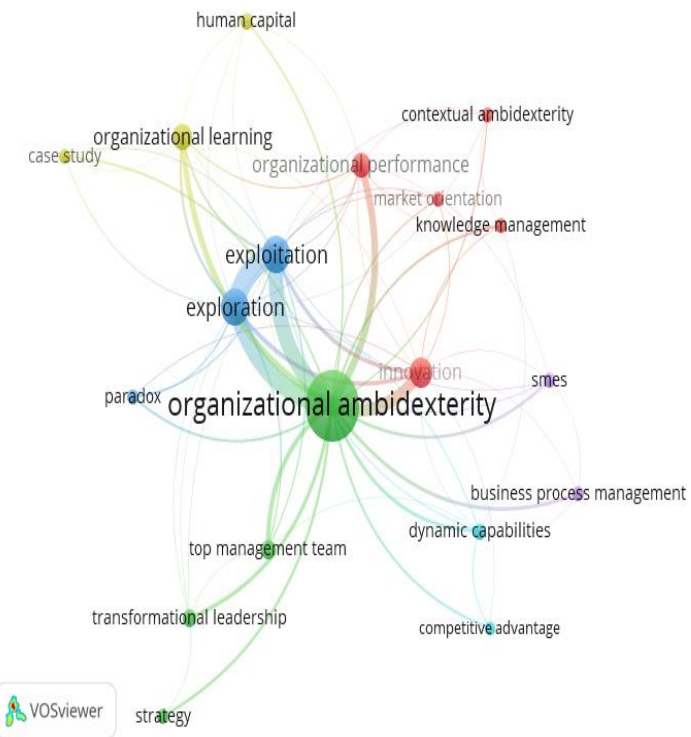

Fig. 4. A bibliometric map of co-occourance of author keywords with network visualization in VOSviewer

Published By:

Blue Eyes Intelligence Engineering \& Sciences Publication 


\section{F. Concept and Terminology}

The results of the current study show that organizational ambidexterity is the most commonly used keyword with 184 occurrences and with a total of 197 links to other keywords (Fig.4). Moreover, exploration and exploitation are the widely linked keywords with occurrences of 44 and 43, and with a total of 112 and 110 links to other keywords respectively.

It is interesting to see a total of nineteen items segregated in five clusters (Fig.4). The first cluster is the biggest having five items including contextual ambidexterity (6 occurrences), innovation (28 occurrences), knowledge management (7 occurrences), market orientation (6 occurrences), and organizational performance (19 occurrences). The second cluster is made up of items such as business process management (7 occurrences), competitive advantage (5 occurrences), dynamic capabilities (8 occurrences), and SMEs (6 occurrences). The third cluster comprises of organizational ambidexterity (184 occurrences), strategy (6 occurrences), the top management team (10 occurrences), and transformational leadership (9 occurrences). The fourth cluster is made up of three items, including, exploration (44 occurrences), exploitation (43 occurrences), and paradox (6 occurrences). The last cluster is made up of three items, where case study (6 occurrences), human capital (8 occurrences), and organizational learning (20 occurrences). Overall, it is interesting to see that after exploitation and exploration as the two common dimensions of organizational ambidexterity, innovation (28), organizational learning (20), organizational performance (19), and top management team (10) are the top items with highest occurrences.

\section{G. Themes of Interest and Major Types}

Based on Fig.4, ambidexterity is the balance among exploitation and exploration and is supported by learning and dynamic capabilities within an organization, helping to achieve competitive advantage. Moreover, organizational learning plays an instrumental part in both exploration and exploitation related activities, within the organization which is also related to organizational performance (Fig.4). The organizational ambidexterity can be achieved through several antecedents (Fig.4). One way is via the structural separation among exploration and exploitation related pursuits within an organization or business unit (44 occurrences, 14 links). This approach is most suitable for large organizations, having ample resources to separate them for both to achieve either exploration or exploitation within a business unit.

Other methods to achieve organizational ambidexterity are suitable more for small and medium-sized organizations (6 occurrences, 6 links) and are achieved via either contextual separation (6 occurrences, 5 links) or through leadership based antecedents (10 occurrences, 6 links). In the contextual separation, a set of systems and processes are developed, which are needed to achieve ambidexterity within a single organizational context, responsible to achieve both the exploration and exploitation related targets. The individuals maintain the balance among exploration and exploitation related contradictory organizational goals, set by the management with the support of organizational systems and processes to deliver ambidexterity.

Lastly, the leadership (or top management team) plays a pivotal role to balance the dual needs of exploration and

Blue Eyes Intelligence Engineering \& Sciences Publication exploitation related targets, set by the organization as evident in Fig.4. The leadership balances the dual targets through their decisions, priorities, and attention to support each of exploration or exploitation related activities within the organization, thus supporting ambidexterity.

To sum up, most of the earlier empirical research is conducted in large organizations with plentiful resources having a focus upon structural separation to achieve ambidexterity. There is less focus on small and medium-sized enterprises because data availability is generally difficult for small and medium-sized organizations in comparison to large organizations. Moreover, more research is needed to fill this void with more studies on the small and medium-sized organizations, especially in the latter two ambidexterity domains.

\section{H. Study Limitations}

The current study holds numerous shortcomings and can be classified into two broad categories. Firstly, the inclusion and search criteria, which currently is based upon organizational ambidexterity as the main keyword to search in the Scopus journal articles, however, the two main dimensions of exploration and exploitation may be used together as additional keywords for future studies as part of the search and inclusion criteria.

Secondly, comparison and combination of other sources such as Web of Science alongside Scopus could be used in prospective studies to achieve a comprehensive and overall coverage of the organizational ambidexterity domain studies. Such a comprehensive, overall coverage may provide superior insights into the organizational ambidexterity domain, which will robustly compare the coverage gaps in either or both the databases for several sub-domains to extend the domain further through future investigations.

\section{CONCLUSION}

The current study presents an overview of the organizational ambidexterity research published in 282 Scopus journal articles between the year 1996 till 2018. The analysis highlights an upward momentum in this area from the year 2014 and onwards, and such a trend is expected to accelerate in times ahead. We have discovered countries such as the United States, the United Kingdom, and China has a large number of collaborations and research publications among its academic institutions and researchers in this domain. Such countries can be a good source of opportunities for researchers around the globe to broaden their research collaborations in this field.

Organizational ambidexterity is composed chiefly of exploration and exploitation as its two principal dimensions used frequently and is linked repeatedly with organizational innovation, organizational learning, and organizational performance. Studies based on organizational performance, business process management, competitive advantage, and small and medium enterprises are the research avenues which the prospective researchers can investigate and carry forth. 


\section{A Bibliometric Analysis of Two Decades of Global Research on Organizational Ambidexterity using the Scopus Database}

\section{APPENDIX}

\section{A. Thesaurus File}

\begin{tabular}{ll}
\hline Panel-A (Original text used in articles) & Panel-B (New label ) \\
\hline organisational ambidexterity & organizational ambidexterity \\
ambidexterity & organizational ambidexterity \\
exploration/exploitation & organizational ambidexterity \\
exploration and exploitation & organizational ambidexterity \\
firm performance & organizational performance \\
performance & organizational performance \\
ambidextrous organisation & organizational ambidexterity \\
ambidextrous organization & organizational ambidexterity \\
ambidextrous organizations & organizational ambidexterity \\
process management & business process management \\
human resources & human capital \\
family firm & smes \\
top management teams & top management team \\
ambidextrous learning & organizational learning \\
organizational change & transformational leadership \\
absorptive capacity & organizational learning \\
scenario planning & strategy \\
\hline
\end{tabular}

B. Top Journals List on Organizational Ambidexterity

\begin{tabular}{|c|c|c|c|}
\hline Rank & Journal & Tp, Tc & Cs 2018, (Publisher) \\
\hline 1 & Journal Of Management & $\begin{array}{l}3, \\
(106)\end{array}$ & 10.96, (Sage) \\
\hline 2 & $\begin{array}{l}\text { International Journal Of } \\
\text { Project Management }\end{array}$ & 3, (79) & 6.41, (ScienceDirect) \\
\hline 3 & $\begin{array}{l}\text { Journal Of Management } \\
\text { Studies }\end{array}$ & $\begin{array}{l}7, \\
(1119)\end{array}$ & $\begin{array}{l}\text { 5.99, } \\
\text { (Wiley-Blackwell) }\end{array}$ \\
\hline 4 & $\begin{array}{l}\text { Academy Of Management } \\
\text { Perspectives }\end{array}$ & $\begin{array}{l}4 \\
(856)\end{array}$ & $\begin{array}{l}\text { 5.92, (Academy of } \\
\text { Management) }\end{array}$ \\
\hline 5 & $\begin{array}{l}\text { Journal Of Product } \\
\text { Innovation Management }\end{array}$ & $\begin{array}{l}7, \\
(187)\end{array}$ & 5.43, (Wiley) \\
\hline 6 & $\begin{array}{l}\text { Journal Of Business } \\
\text { Research }\end{array}$ & $3,(24)$ & 5.32, (ScienceDirect) \\
\hline 7 & Organization Science & $\begin{array}{l}11, \\
(3041)\end{array}$ & 4.76, (Informs) \\
\hline 8 & Long Range Planning & $\begin{array}{l}4, \\
(180)\end{array}$ & 4.42, (ScienceDirect) \\
\hline 9 & $\begin{array}{l}\text { Technological Forecasting } \\
\text { And Social Change }\end{array}$ & $\begin{array}{l}7, \\
(122)\end{array}$ & 4.32, (ScienceDirect) \\
\hline 10 & $\begin{array}{l}\text { Human Resource } \\
\text { Management }\end{array}$ & $\begin{array}{l}8, \\
(184)\end{array}$ & 4.28, (Wiley) \\
\hline 11 & $\begin{array}{l}\text { European Management } \\
\text { Journal }\end{array}$ & $\begin{array}{l}3, \\
(114)\end{array}$ & 3.88, (ScienceDirect) \\
\hline 12 & $\begin{array}{l}\text { Creativity And Innovation } \\
\text { Management }\end{array}$ & $\begin{array}{l}4, \\
(112)\end{array}$ & 3.11, (Wiley) \\
\hline 13 & $\begin{array}{l}\text { Business Process } \\
\text { Management Journal }\end{array}$ & $7,(25)$ & 2.98, (Emerald) \\
\hline 14 & Management Decision & $\begin{array}{l}6, \\
(121)\end{array}$ & 2.74, (Emerald) \\
\hline 15 & $\begin{array}{l}\text { International Journal Of } \\
\text { Human Resource } \\
\text { Management }\end{array}$ & $6,(74)$ & $\begin{array}{l}\text { 2.71, (Taylor \& } \\
\text { Francis) }\end{array}$ \\
\hline
\end{tabular}

\section{REFERENCES}

1. D. Lavie, U. Stettner, and M. L. Tushman, "Exploration and exploitation within and across organizations," Acad. Manag. Ann., vol. 4, no. 1, pp. 109-155, 2010.

2. D. A. Levinthal and J. G. March, "The myopia of learning," Strateg. Manag. J., vol. 14, no. 2 S, pp. 95-112, 1993.

3. C. O'Reilly and M. Tushman, "Organizational Ambidextiry: Past, Present, and Future," Acad. Manag. Perspect., vol. 27, no. 4, pp. 324-338, 2013.

4. Z.-L. He and P.-K. Wong, "Exploration vs. Exploitation: An Empirical Test of the Ambidexterity Hypothesis," Organ. Sci., vol. 15, no. 4, pp. 481-494, 2004.

5. S. Raisch, J. Birkinshaw, G. Probst, and M. L. Tushman, "Organizational Ambidexterity: Balancing Exploitation and Exploration for Sustained Performance,” Organ. Sci., vol. 20, no. 4, pp.
685-695, 2009.

6. P. Junni, R. M. Sarala, S. Y. Tarba, Y. Liu, and C. L. Cooper, "Guest Editors' Introduction: The Role of Human Resources and Organizational Factors in Ambidexterity," Hum. Resour. Manage., vol. 54, no. December, pp. s1-s28, 2015.

7. R. Rialti, G. Marzi, M. Silic, and C. Ciappei, "Ambidextrous organization and agility in big data era: The role of business process management systems," Bus. Process Manag. J., vol. 24, no. 5, pp. 1091-1109, 2018.

8. Z. Simsek, "Organizational ambidexterity: Towards a multilevel understanding," J. Manag. Stud., vol. 46, no. 4, pp. 597-624, 2009.

9. Z. Wei, Y. Yi, and H. Guo, "Organizational learning ambidexterity, strategic flexibility, and new product development," J. Prod. Innov. Manag., vol. 31, no. 4, pp. 832-847, 2014.

10. W. Bodwell and T. J. Chermack, "Organizational ambidexterity: Integrating deliberate and emergent strategy with scenario planning," Technol. Forecast. Soc. Change, vol. 77, no. 2, pp. 193-202, 2010.

11. I. Prieto-Pastor and V. Martin-Perez, "Does HRM generate ambidextrous employees for ambidextrous learning? The moderating role of management support," Int. J. Hum. Resour. Manag., vol. 26, no. 5, pp. 589-615, 2015.

12. C. R. Li and C. J. Lin, "The nature of market orientation and the ambidexterity of innovations," Manag. Decis., vol. 46, no. 7, pp. 1002-1026, 2008.

13. C. Andriopoulos and M. W. Lewis, "Managing Innovation Paradoxes: Ambidexterity Lessons from Leading Product Design Companies,' Long Range Plann., vol. 43, no. 1, pp. 104-122, 2010.

\section{AUTHORS PROFILE}

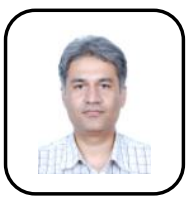

Asad Amjad, is currently a $\mathrm{PhD}$ scholar at Azman Hashim International Business School (AHIBS), Universiti Teknologi Malaysia. He works for National University of Sciences and Technology (NUST), Pakistan as an Assistant Professor in Management and Human Resource Division at NUST Business School. He holds an MBA from The University of Sheffield, United Kingdom, and a master's in computer sciences from Pakistan. He is also a graduate of science and technology park program from South Korea. His research and teaching interests include organizational theory and design, managing organization behavior, and innovation and technology management. He serves as a reviewer for Scopus journals in the area of leadership, strategic management, technology management and innovation. As a $\mathrm{PhD}$ fellow, he is in process of publishing his manuscripts in the area of organizational ambidexterity, and performance among the small and medium enterprises.

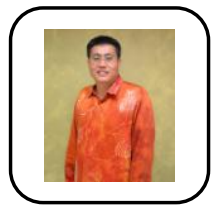

Khalil Md Nor, is a Professor at the Azman Hashim International Business School, Johor Bahru campus, Universiti Teknologi Malaysia. His research interests are in the area of technology adoption, strategic information systems planning, e-commerce, knowledge management and organizational management. He holds a Bachelor of Science in economics and industrial management and a Maste of Science in public management and policy from Carnegie Mellon University, United States. His $\mathrm{PhD}$ is from Southern Illinois University, United States in the area of business administration. He is an author of three books, seven book chapters, seventy conference papers, and more than ninety journal articles listed in Scopus and Web of Science. He has supervised more than one hundred and thirty students at the Bachelors, Masters and $\mathrm{PhD}$ levels.

\section{Published By:} Blue Eyes Intelligence Engineering \& Sciences Publication 